\title{
POLITISASI ULAMA PADA PILPRES 2019 PERSPEKTIF KIAI SILO DI KABUPATEN PASURUAN
}

\author{
Miftahul Huda \& M. Dayat \\ Universitas Yudharta Pasuruan \\ miftahulhuda@yudharta.ac.id, dayat@yudharta.ac.id
}

\begin{abstract}
Abstrak:
Kehebohan pemilihan Presiden 2019 telah ramai, terutama di media sosial yang telah dimulai sejak awal 2018. Berdasarkan survei Lembaga Penelitian dan Pengembangan KOMPAS pada pertengahan 2018, dinyatakan bahwa konflik politik antara pendukung calon Presiden dan calon Wakil Presiden lebih parah dan terjadi di media sosial dengan persentase $71,8 \%$ dibandingkan dengan konflik dalam hubungan langsung dengan persentase $<10 \%$. Di Pasuruan, Jawa Timur, misalnya, apa pun yang dikatakan oleh ulama tidak diragukan lagi akan dipengaruhi oleh santri dan jama'ah, dan bahkan tanpa harus memperhitungkan baik atau buruknya hal itu. Secara konseptual, penelitian ini berorientasi pada makna Kiai mursyid thariqat terhadap fenomena politisasi ulama dalam pemilihan Presiden 2019. Metode yang digunakan dalam penelitian ini adalah fenomenologi kualitatif. Pada kenyataannya setelah pemilihan presiden masih ada polarisasi antara pendukung dan bahkan permusuhan. Seorang Kiai adalah tokoh karismatik yang dihormati dan merupakan panutan bagi masyarakat. Dalam kontestasi pemilu seorang Kiai tidak boleh mempraktikkan politik, tetapi politik nasional yang berupaya membantu TNI, POLRI dan penyelenggara pemilu untuk menyelaraskan suasana dan kampanye menuju pemilihan damai, jujur, dan adil.
\end{abstract}

Kata kunci: politik, pilpres, ulama

The excitement of the 2019 presidential election has been bustling, especially on social media which began in early 2018. Based on a KOMPAS Research and Development Institute survey in mid-2018, it was stated that political conflicts between Presidential and Vice President candidates' supporters were worse and occurred on social media with a percentage of $71,8 \%$ compared to conflicts in direct relationship with a percentage $<10 \%$. In Pasuruan, East Java, for example, whatever is said by the ulema will undoubtedly be influenced by santri and jama'ah, and even without having to calculate the good or bad. Conceptually, this research is oriented to the meaning of the murshid ulama scholars about the phenomenon of ulama politicization in the 2019 presidential election. The method used in this research is qualitative phenomenology. In reality after the presidential election there is still a polarization between supporters and even hostility. An ulama is a respected charismatic figure and is a role model for the community. In the election contestation, a Kiai must not practice politics, but national politics that seeks to help the TNI, POLRI and election organizers to harmonize the atmosphere and campaign towards peaceful, honest and fair elections.

Keywords: political, the presidential election, ulama 


\section{Pendahuluan}

Tahun 2019 Indonesia mempunyai hajat besar yaitu pesta demokrasipemilihan umum presiden dan calon wakil presiden yang selalu dilaksanakan dalam 5 tahunan. Dalam kontestasi politik di Indonesia akhir-akhir ini peran ulama termasuk Kiai, ustadz, atau pemimpin ormas tak terhindarkan. Para ulama yang seharusnya sebagai tokoh agama, mengaji, penceramah, dan berdakwah kini sibuk menjadi juru kampanye pada salah satu calon tertentu. Lebih dari itu, banyak ulama yang pada akhirnya turut serta menjadi bagian dari salah satu pasangan calon untuk bersaing pada kubu calon lainnya.

Kehebohan pilpres 2019 telah ramai diperbincangkan terutama di media sosial. Sebagaimana hasil survey Lembaga Penelitian dan pengembangan (LITBANG) KOMPAS pada pertengahan tahun 2018 dalam konteks kedewasaaan berpolitik terjadi pertentangan antar kubu pasangan calon presiden (Capres) dan calon wakil presiden (Cawapres) dan lebih parahnya lagi banyak yang terjadi melalui media social sebesar $71,8 \%$ di dalam pertentangan dalam pergaulan langsung dengan prosentase 9,1 persen.

Dalam kontestasi politik Pilpres 2019 faktanya begitu jelas, bahwa telah terjadi fenomena politisasi ulama, dimana masing-masing kubu bayak menggunakan istilah dan melegitimasi peran ulama sebagai magnet politik guna mendapatkan lebih banyak perhatian dan simpatisan di Negara yang mayoritas penduduknya memeluk agama Islam ini. Petinggi PBNU, KH. Ma'rif Amin berpartisipasi aktif sebagai calon Wapres dari Ir. Joko Widodo sebagai kubu-1 (nomor urut satu). Sementara kubu-2 (nomor urut dua) H. Prabowo Subianto dan Sandiaga Uno juga mendung-dengunkan ulama dari kubunya melalui penggunaan istilah dukungan ijtima' ulama. Meskipun demikian, banyak juga Kiai atau ulama yang mulanya cenderung pasif dalam partisipasi politiknya, menyayangkan fenomana tersebut.

Keberagaman perspektif atau mainstreaming para Kiai dalam menyikapi politisasi ulama pada kontestasi Pilpres 2019 sebenarnya sudah menjadi suatu keniscayaan. Namun demikian, membina santri dan jama'ahnya agar lebih cerdas dalam berpolitik menjadi tugas penting yang harus dilakukan oleh seorang Kiai. Sehingga hasil dari penelitian ini diharapkan dapat membuka cakrawala berfikir para santri dan umat Islam agar lebih cerdas dalam menerima dawuh (pernyataan) dan sikap para Kiai silo atas partisipasinya dalam kontestasi politik baik pada momentum Pilpres maupun Pilkada untuk menghindari konflik potensial akibat pertentangan politik. Selain itu, tujuan dari penelitian ini adalah meberikan informasi kepada publik mengenai pluralitas perspektif para ulama pada umumnya dan para Kiai silo di Kabupaten Pasuruan pada khususnya dalam menyikapi politisasi ulama pada kontestasi politik dalam Pilpres 2019 di Indonesia.

Menurut Hoogerwerf ${ }^{1}$ mengatakan bahwa partisipasi politik adalah keikutsertaan pada kebijaksanaan pemerintah dan pada terwujudnya kebijaksanaan itu. Dari berbagai pendapat di atasa terlihat bahwa partisipasi politik mencakup aspek-aspek yang sangat luas termasuk juga tingkah laku politik dan pemilihan penguasa di dalam suatu kegiatan politik yang disebut pemilihan umum.

\footnotetext{
${ }^{1}$ Hoogerwerf A. Ujung Kulon: the land of the last Javan Rhinos. Part V. The Javan Deer. (Leiden E. J. Brill, 1970), 189.
} 
Pengertian umum mengenai partisipasi menurut Alfian yaitu keikutsertaan suatu kelompok masyarakat dalam kehidupan politik, misalnya: memilih pemimpin negara, menghadiri rapat umum, menjadi anggota suatu partai dan lain-lain. ${ }^{2}$

Indonesia merupakan Negara dengan populasi penduduk Muslim terbesar di dunia, dimana 88\% penduduknya memeluk agama Islam. Runtuhnya rezim Orde Baru pada Tahun 1998 telah mengantarkan perubahan sistem pemerintahan yang sebelumnya otoriter ke dalam masa transisi demokrasi. Transisi demokrasi yang dijalankan di Indonesia mendapatkan pujian dari Menlu AS Hillary Clinton yang menganggap Indonesia sebagai panutan demokrasi bagi dunia Muslim. Demikian juga, Presiden Obama memuji demokrasi Indonesia sebagai contoh yang baik bagi dunia. $^{3}$

Keterlibatan dalam perkumpulan kewargaan dan ketertarikan terhadap politik juga cenderung berpengaruh langsung pada partisipasi politik. Menurut Olsen Partisipasi dalam perkumpulan-perkumpulan non politik yang bersifat sukarela dan menyalurkan kepentingan khusus (special interest), pada saatnya akan membuat seseorang aktif secara politik. Ada berbagai alasan mengapa partisipasi semacam ini bisa meningkatkan aktivitas politik seseorang: (1) partisipasi itu memperluas wawasan seseorang mengenai minat, kepentingan dan kepedulian, sehingga urusan-urusan publik menjadi pentng baginya. (2) partisipasi itu membawa seseorang berhubungan dengan orang-orang baru beraneka ragam, dan ini membuatnya peduli pada masalah-masalah public, dan menjadi aktif dalam kegiatan politik. (3) partisipasi itu membantu menambah informasi seseorang, melatihnya dalam berinteraksi sosial, membuatnya lebih terampil dalam memimpin dan mengambil sumber daya-sumber daya yang dibutuhkan untuk aksi politik yang efektif. 4

Keterlibatan dalam kelompok sosial melalui kelompok sosial keagamaan seperti NU dan Muhammadiyah, dan kelompok-kelompok sosial non keagamaan seperti karang taruna, arisan, rapat, rukun tetangga (RT), organisasi profesi dan organisasi hobi, membuka informasi dan komunikasi mengenai masalah publik, sehingga mendorong warga Negara terkait dengan masalah tersebut. Selain itu orang-orang yang terlibat dalam kelompok sosial sangat mungkin siap terlibat dalam mobilisasi politik oleh kelompok tersebut. ${ }^{5}$

Definisi Kiai dalam Kamus Besar Bahasa Indonesia (2014) adalah sebutan bagi alim ulama (orang yang cerdik dan pandai dalam agama Islam). Sedangkan dalam Ensiklopedi Islam Indonesia disebutkan bahwa Kiai di kalangan masyarakat tradisional Jawa, merupakan tokoh keagamaan kharismatik yang bisa dibandingkan dengan ajengan di masyarakat Jawa Barat, syekh di masyarakat Minangkabau Sumatera Barat. ${ }^{6}$ Untuk penyebutan istilah kiai di Indonesia memang berbeda-beda, tetapi substansinya memiliki peran dan tugas yang sama.

\footnotetext{
${ }^{2}$ Alfian, Transformasi Sosial Budaya dalam Pembangunan Nasional. Cet-1, (Jakarta: UI-Press, 1986), 70

${ }^{3}$ Luthfi Assyaukani, Ideologi Islam Dan Utopia: Tiga Model Negara Demokrasi Di Indonesia. (Jakarta: Freedom Institut, 2011)

4 , Saiful Mujani Dkk. Kuasa Rakyat. (Jakarta: Mizan Publika, 2012), 318.

5 Ibid

${ }^{6}$ Departemen Agama RI, Ensiklopedi Islam di Indonesia, (Jakarta: Direktorat Pembinaan Kelembagaan Agama Islam, 1992), 562.
} 
Di berbagai daerah di Indonesia penggunaan istilah kiai berbeda dengan istilah ulama. Horikoshi (1976) dan Mansurnoor (1990) membedakan kiai dan ulama dalam peran dan pengaruhnya dalam masyarakat. Ulama adalah istilah yang lebih umum dan merujuk kepada seorang muslim yang berpengetahuan. Kaum ulama adalah kelompok yang secara jelas mempunyai fungsi dan peran sosial sebagai cendekiawan penjaga tradisi yang di anggap sebagai dasar identitas primodial individu dan masyarakat. Dengan kata lain fungsi ulama yang terpenting adalah peran ortodoks dan tradisional mereka sebagai penegak keimanan dengan cara mengajarkan doktrin-doktrin keagamaan dan memelihara amalan-amalan keagamaan ortodoks di kalangan umat Islam. ${ }^{7}$. Istilah ulama secara luas di gunakan di dunia Islam. Di Indonesia berbagai istilah lokal di gunakan untuk menunjukan berbagai tingkat keulamaan, dan istilah yang paling di gunakan untuk menunjukan berbagai tingkat keulamaan yang lebih tinggi adalah kiai.

Kiai merupakan elemen yang paling esensial dari suatu pesantren. Seringkali ia adalah pendiri pesantren itu sendiri. Sudah sewajarnya bahwa pertumbuhan suatu pesantren semata-mata bergantung kepada kemampuan pribadinya. Istilah kiai di Indonesia tidak hanya mengandung muatan makna ahli agama, tetapi juga memiliki muatan sosiologis-antropologis. Ketokohan kiai merupakan ciri khas dalam masyarakat pesantren, ini terjadi karena kultur masyarakat Indonesia yang paternalistik tapi individu kiai sendiri merupakan gelar yang tercipta melalui proses teologis. Berdasarkan karakternya dalam istilah jawa Kiai diklasifikasikan sebagai berikut:

1. Kiai silem, yaitu Kiai yang tidak pernah atau jarang muncul ke permukaan (publik), hanya ber-dzikir dan mendo'akan eksistensi perdamaian dan untuk kemaslahatan umat manusia di dunia dan akhirat.

2. Kiai silo, yaitu ulama yang berjuang memiliki pondok pesantren, yayasan, lembaga, pendidian, organisasi, majelis ta'lim termasuk juga majelis dzikir dan ilmu. Ia adalah sosok kiai yang pintar nandur (menanam) benih generasi ilmunya kelak. Kiai silo biasanya seorang tokoh panutan masyarakat yang dihormati karena alim dan memiliki suri tauladan yang baik, banyak dijadikan rujukan masyarakat untuk datang kepadanya. Kiai silo juga biasanya cenderung pasif dalam konstelasi politik praktis, ia akan memberikan respon reaktif apabila suasana permukaan (publik) dalam keadaan keruh untuk mengupayakan 'islah' antara pihak-pihak yang berkonflik untuk berdamai. Kiai mursyid thariqat merupakan bagian dari kategori ini.

3. Kiai silat, yaitu Kiai yang mempunyai atau tidak mempunyai pondok pesantren, Kiai silat biasanya seorang tokoh panutan masyarakat karena biasanya diundang untuk memberikan ceramah dalam majelis ta'lim tertentu. Kiai silat juga dinobatkan pada Kiai yang aktif dalam organisasi masyarakan keagamaan, organisasi sosial dan politik. Biasanya Kiai kategori ini acapkali menjadi 'corong' atau 'echo' untuk kepentingan politik dan kekuasaan.

Secara konseptual penelitian ini berorientasi pada pemaknaan para Kiai mursyid thariqat terhadap fenomena politisasi ulama dalam Pilpres 2019. Sehingga metode yang relevan untuk digunakan dalam penelitian ini adalah kualitatif fenomenologi. Dimana fenomenologi berusaha untuk memahami bagaimana

${ }^{7}$ Hiroko Horikoshi, Kiai dan Perubahan Sosial, (Jakarta: P3M, 1987), 232. 
seseorang mengalami dan memberi makna pada sebuah pengalaman. Fenomenologi berusaha mendekati objek kajian secara konstruktivis serta pengamatan yang cermat, dengan tidak menyertakan prasangka oleh konsepsi-konsepsi manapun sebelumnya. Fenomenologi akan berusaha memahami pemahaman informan terhadap fenomena yang muncul dalam kesadarannya, serta fenomena yang dialami oleh informan dan dianggap sebagai entitis sesuatu yang ada dalam dunia. Metode ini digunakan karena struktur kesadaran dalam pengalaman ini pada akhirnya membuat makna dan menentukan isi dari pengalaman.

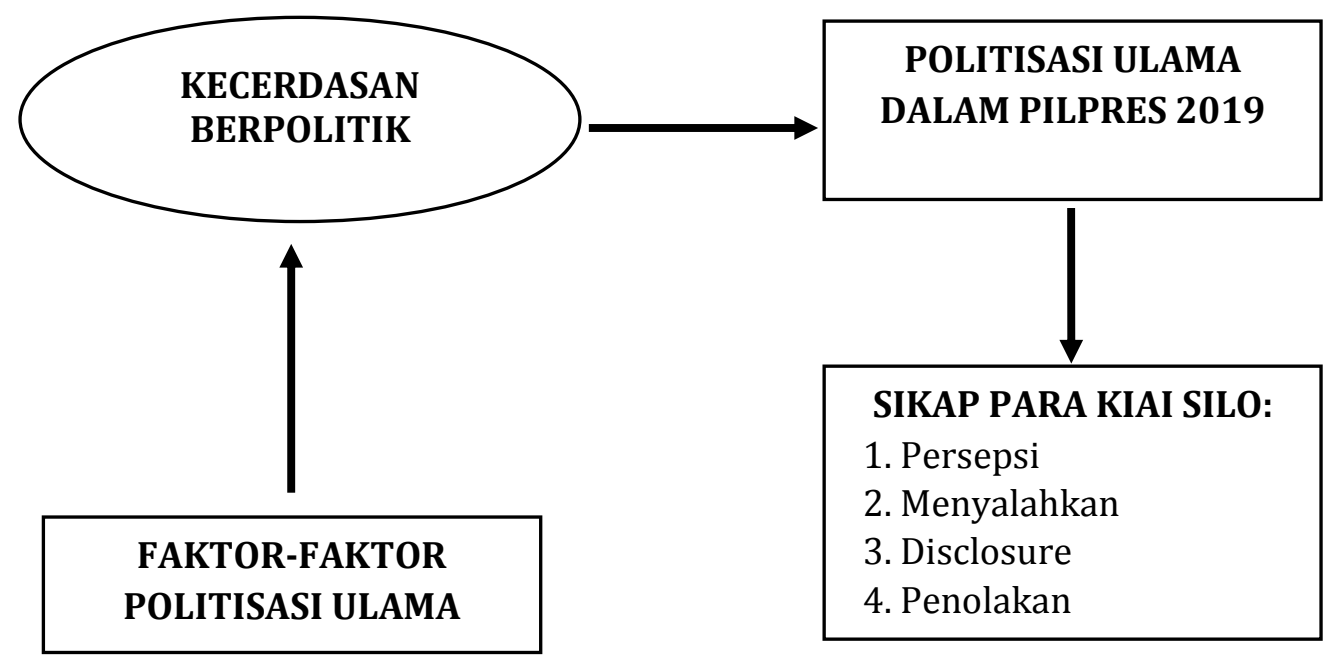

\section{Gambar 1. Kerangka Pemikiran Penelitian}

\section{Metode Penelitian}

Penelitian ini merupakan penelitian kualitatif fenomenologis. Metode ini dipilih untuk mendeskripsikan suatu fenomena pada area populasi tertentu yang bersifat faktual secara sistematis dan akurat, dalam hal ini persepsi para Kiai silo terhadap politisasi ulama dalam Pilpres 2019. Populasi yang menjadi sasaran penelitian adalah para Kiai pengasuh pondok pesantren yang tidak terlibat secara langsung dalam kontestasi politik, baik sebagai calon eksekutif maupun calon anggota legislaif di daerah Kabupaten Pasuruan.

Penentuan obyek penelitian berdasarkan track and record Kiai pemangku pondok pesantren dengan kategori Kiai tidak terlibat secara langsung sebagai aktor dan tokoh politik di Kabupaten Pasuruan. Adapun untuk menentukan sampel penelitian ini dipergunakan teknik purposive sampling dengan mengambil enam pondok pesantren di enam Kecamatan di wilayah Kabupaten Pasuruan dengan kriteria Kiai yang mempunyai pondok pesantren, berthoriqoh serta menjabat sebagai tokoh ormas. Pengumpulan data dalam penelitian ini dilakukan dengan melakukan observasi dan wawancara dengan para Kiai yang dipilih sebagai obyek penelitian berdasarkan kriteria yang telah ditentukan. Untuk mengukur status Kiai, variabel penelitian ini terdiri dari dua variabel dependent, yaitu variabel persepsi masyarakat terhadap track and record Kiai dalam konstelasi politik dan variabel persepsi masyarakat terhadap kiai dalam pemberdayaan di bidang kerukunan umat beragama. 
Adapun teknik pengumpulan data yang akan digunakan dalam penelitian ini adalah sebagai berikut: Observasi adalah pengamatan dan pencatatan dengan sistemis atas fenomena yang akan atau sedang diteliti. Observasi dalam penelitian ini digunakan untuk mengamati lingkungan sosial subyek penelitian. Teknik ini menuntut adanya pengamatan dari peneliti baik secara langsung maupun tidak langsung terhadap objek penelitian. Instrumen yang dapat digunakan yaitu lembar pengamatan, panduan pengamatan. Beberapa informasi yang diperoleh dari hasil observasi antara lain: ruang (tempat), pelaku, kegiatan, objek, perbuatan, kejadian atau peristiwa, waktu, dan perasaan. ${ }^{8}$

Wawancara, menurut Hadi wawancara merupakan metode pengumpulan data dengan tanya jawab sepihak yang dikerjakan dengan sistemis dan berlandaskan tujuan penelitian. ${ }^{9}$ Wawancara adalah percakapan dengan maksud tertentu. Percakapan itu dilakukan oleh dua pihak, yaitu pewawancara (interviewer) yang mengajukan pertanyaan dan diwawancarai/responden (interviewee) yang memberikan jawaban atas pertanyaan itu. ${ }^{10}$ Danim menambahkan bahwa pada penelitian kualitatif, wawancara mendalam dapat dilakukan dengan dua cara. Pertama, wawancara sebagai strategi utama dalam mengumpulkan data. Pada konteks ini, catatan data lapangan yang diperoleh berupa transkrip wawancara. Kedua, wawancara sebagai strategi penunjang teknik lain dalam mengumpulkan data, seperti observasi partisipan, analisis dokumen, dan fotografi. Dalam penelitian ini wawancara digunakan untuk menggali informasi tentang konsep diri remaja putri dalam menghadapi menarche. Serta digunakan untuk mengklarifikasi informasi yang sudah didapat dengan keterangan dari significant others. ${ }^{11}$

\section{Pembahasan dan Hasil Penelitian Faktor-Faktor Politisasi Ulama}

Pemilu akhir-akhir ini para aktor politik banyak yang menggunakan isu suku, agama, ras dan antar golongan (SARA) sebagai jurus utama untuk memenangkan pilihan politiknya. Faktor terbesar salah satunya adalah dengan cara memainkan Politik Agama untuk memenangkan salah satu calon. Politik agama menjadi hal yang sangat sensitif di Indonesia. Mayoritas penduduk Indonesia memeluk agama islam, jika ada salah satu pasangan calon ada yang non muslim atau yang minim masalah agama, maka isu itu akan terus digulirkan, meskipun calon tersebut record kepemimpinannya mempunyai catatan emas. Ketika politik agama dimainkan akan berdampak pada konflik antar golongan yang dapat menimbulkan kebencian serta nantinya berujung pada perpecahan. Menurut Zainul Ma'arif mengatakan bahwasannya pemicu politisasi agama ialah kolaborasi antara agamawan/ulama garis keras yang kekanak-kanakan secara negatif dengan politisi yang punya hasrat mengebu-gebu untuk menjadi penguasa secara negatif. ${ }^{12}$

\footnotetext{
8 Noor, Juliansyah. Metodologi Penelitian Skripsi, Tesis dan Disertasi Karya Ilmiah. Cetakan Kedua. (Jakarta: Kencana Prenada Media, 2012), 140.

${ }_{9}$ Hadi, Sutrisno. Penelitian Research. (Yogyakarta: BPFE, 2004)

${ }^{10}$ Lexy J Moleong, Metode Penelitian Kualitatif. (Bandung: PT. Remaja Rosdakarya, 2009)

${ }^{11}$ Sudarwan Danim, Menjadi Peneliti kualitatif, (Bandung: Pustaka Setia, 2002).

12 https://redaksikota.com/news/nasional/13/02/2018/42700/pengamat-nilai-munculnyapolitisasi-agama-dipengaruhi-2-faktor-ini.php. Di akses pada Rabu, 22 Mei 2019 pukul 02:45
} 


\section{Kecerdasan Berpolitik}

Masyarakat harus bisa menilai tentang ini, karena ketika isu Sara yang dimainkan maka mereka yang menjadi korban dari keganasan politikus. Ketika masyarakat cerdas dalam memilih, para politisi akan melakukan segala cara dengan selalu berpihak dan mengutamakan kepentingan rakyat, visi-misinya jelas, Programnya bagus serta jujur dan adil jika ingin menang. Proses demokrasi harus dimulai dengan doktrinsai tentang poltik itu sendiri yang ditujukan untuk pembangunan agar ketika pesta demokrasi digelar, benar - benar para calon menyampaikan kapabilitas serta kecakapannya dalam memimpin dan memajukan pembangunan di negara. Dan ketika masyarakat tersebut cerdas dalam meilih maka Negara akan maju dan sejahtera

\section{Politisasi Ulama dalam Pilpres 2019}

Dalam kontestasi politik pada pilpres tahun 2019 terjadi politisasi ulama di masing-masing kubu. Salah satu faktor terbesarnya adalah dengan cara memainkan Politik Agama untuk memenangkan salah satu calon. Politik agama menjadi hal yang sangat sensitif di Indonesia, terbukti pada pilkada DKI tahun 2018 para elite politik berhasil memenangkan dengan cara memainkan isu Agama.

Dalam Pilpres 2019 ini terlihat begitu jelas, faktanya terjadi fenomena politisasi ulama dalam masing-masing kubu saling klaim dalam istilah ulama untuk menjadi daya tarik, menyakinkan serta simpatisan para masyarakat Indonesia yang mayoritas beragama islam. Dari kubu $01 \mathrm{H}$. Ir. Joko Widodo menggandeng Petinggi salah satu Ormas islam terbesar di Indonesia yakni Prof. Dr. (HC) KH. Makruf Amin dari Nahdlatul Ulama (NU), sementara dari kubu 02 H. Prabowo Subianto dan H. Sandiaga Salahudin Uno juga mendenggung-denggungkan istilah ijtima' ulama. Karena pasangan tersebut berdasarkan hasil ijtima' ulama. Dalam ijtima' ulama juga menghasilkan sebutan bahwa H. Sandiaga Salahudin Uno adalah santri Millenial.

Sikap Para Kiai Silo. Para Kiai silo dikabupaten pasuruan memaknai kontestasi pilpres merupakan kegitan rutinitas dalam rangka menciptakan demokrasi di Indonesia. mereka sepakat untuk menjadikan pemilu ini yang adil, damai dan tidak saling menghujat. Bahkan para Kiai kebanyakan netral dalam menentukan hak politiknya. Menurut KH. Sholeh Bahruddin pengasuh pondok pesantren Ngalah kecamatan Purwosari sekaligus mursyid thoriqoh naqsabandiyah beliau mengatakan saya, istri beserta anak cucu saya semuanya netral, dan tidak mencoblos. Tetapi kalau santri, jama'ah dan alumni wajib untuk mencoblos. Beliau mengibaratkan seperti pabrik rokok ketika mesinnya terjual maka produksi rokok tersebut akan berhenti, tetapi kalau rokoknya yang terjual maka pabrik tersebut akan mendapat keuntungan yang besar. Mengenai pandangannya tentang politisasi ulama beliau mengatakan Kiai itu ada 2 macam ada Kiai sunan yang dalam hal ini dia memposisikan sebagai seorang yang mengajarkan ilmu agama melalui dakwah, rutinan, mengajar kitab kuning di pesantren dan sama sekali tidak berpolitik praktis. Yang kedua adalah Kiai sultan yang dalam berdakwahnya masuk pada jabatan politik di DPR, Bupati, Gubernur, dll. 
Menurut pengasuh podok pesantren keramat kecamatan kraton sekaligus mursyid thoriqoh qodiriyah yang akrab dipanggil gus dayat, beliau mengatakan segogyanya Kiai tidak ikut dalam politik praktis, karena sosok Kiai merupakan sosok yang sangat dihormati serta menjadi suri tauladan bagi santri dan orang banyak dan menjadi rujukan tingkah lakunya. Kiai sebaiknya berpolitik kebangsaan yang menjadi peredam serta penyejuk untuk menciptakan perdamian. Mengenai politisasi ulama itu harus dipisahkan antara agama dan politik.

Memang dalam pilpres tahun 2019 ini sempat terjadi polarisari, sebagian mereka saling menyalahkan antar kubu, dan banyak Kiai juga yang membubuhkan tanda tangannya untuk menyerukan mendukung salah satu pasangan calon, serta banyak pula yang langsung terjun untuk berkampanye di tengah-tengah masyarakat.

Namun pasca pilpres berlangsung para Kiai juga ikut meredam suasana dengan bersama-sama jajaran TNI, POLRI untuk mengkampayekan pemilu damai. Menurut Zainul Faizin ketua KPU kabupaten Pasuruan dari KPU memang ada upaya bekerjasama melaui ormas-ormas dan tokoh-tokoh masyarakat untuk meredam suasana yang sempat memanas, diharapkan para tokoh-tokoh tersebut bisa memberikan pengertian pada masyarakat di desa-desa yang gesekannyan terlalu keras akibat isu-isu selama pilpres berlangsung hasilnya mas faizin menilai pasca pemilu berjalan dengan baik dan tidak ada konflik apapun mereka saling menerima dengan keputusan KPU.

Ketua MUI Kabupaten Pasuruan KH Nurul Huda mengatakan, agama tidak bisa di campur adukkan dengan politik ketika ada tokoh agama yang masuk pada dunia politik tidak boleh membawa atribut ormas atau jabatannya untuk dijadikan alat meraih suara. "Saya melihat KPU dan semua unsur sudah melaksanakan Pemilu yang jujur, adil dan transparan. Mudah-mudahan, jerih payah KPU, Bawaslu, TNI, Polri dan unsur semuanya menjadi amal ibadah yang Insyaallah barokah dan bisa diterima," jelasnya. ${ }^{13}$

Terkait pasca pilpres para tokoh sepakat untuk menolak adanya kerusuhan yang disebabkan oleh hasil dari pemilu menurut KH Achmad Rifa'i, selaku tokoh agama Kecamatan Bangil, menolak keras akan adanya gerakan People Power dengan mengapresiasi baik kinerja seluruh penyelenggara Pemilu baik Komisi Pemilihan Umum (KPU) dan Bawaslu khususnya di Kabupaten Pasuruan. ${ }^{14}$ Sedangkan Menurut KH. Afif pelaksanaan Pemilu 2019 di Kabupaten Pasuruan, Jatim, mendapat dukungan dari masyarakat. Mulai tahap distribusi hingga proses penghitungan suara dilakukan secara jujur, transparan, adil dan demokratis."Pelaksanaan pemilu 2019 sudah berjalan dengan baik," tandas KH. Moh Afif, Ketua MUI Kecamatan Purwosari Kabupaten Pasuruan. ${ }^{15}$ Sedangakan kapolres kabupaten pasuruan juga mempunyai program diantaranya Deklarasi kampanye damai,Jalin kerjasama dengan tokoh masyarakat dan agama,Komunikasi intensif

13 https://surabaya.tribunnews.com/2019/05/03/pemilu-adil-dan-transparan-ini-pesansejumlah-tokoh-agama-di-pasuruan-pasca-pemilu-2019. Di akses pada Rabu, 22 Mei 2019 pukul $14: 50$

$14 \mathrm{https} / /$ m.suara.com/partner/content/suarajatimpost/2019/05/20/062341/tokoh-agamakecamatan-bangil-turut-menolak-keras-people-power. Di akses pada Rabu, 22 Mei 2019 pukul 15:03 15 https://sabdanews.com/2019/05/18/mui-kecamatan-tosari-pasuruan-serukan-masyarakat-takterprovokasi-people-power/. Di akses pada Rabu, 22 Mei 2019 pukul 15:15. 
dengan Panwaslu dan Bawaslu, Imbau masyarakat tak terpengaruh medsos,Ajak partisipasi masyarakat dalam menjaga keamanan dan kerteriban

\section{Penutup}

Pesta demokrasi adalah kegiatan rutinitas untuk memilih pemimpin, tidak seyogyanya pasca pilpres masih saja terjadi polarisasi antar pendukung bahkan terjadi permusuhan. Seorang Kiai adalah sosok kharismatik yang disegani ,dihormati , serta menjadi suri tauladan bagi masyarakat, dalam kontestasi pemilu seorang Kiai hendaklah tidak berpolitik praktis, melainkan politik kebangsaan yang berusaha membantu TNI, POLRI serta penyelenggara pemilu untuk mendamaikan suasana serta selalu mengkampayekan pemilu yang damai, jujur, adil, dan LUBER.

\section{Daftar Pustaka}

Alfian, Transformasi Sosial Budaya dalam Pembangunan Nasional. Cet-1, (Jakarta: UI-Press, 1986)

Assyaukani, Luthfi. Ideologi Islam Dan Utopia: Tiga Model Negara Demokrasi Di Indonesia. (Jakarta: Freedom Institut, 2011)

Danim, Sudarwan. Menjadi Peneliti kualitatif. (Bandung: Pustaka Setia, 2002)

Departemen Agama RI, Ensiklopedi Islam di Indonesia, (Jakarta: Direktorat Pembinaan Kelembagaan Agama Islam, 1992)

Hadi, Sutrisno. Penelitian Research. (Yogyakarta: BPFE, 2004)

Horikoshi, Hiroko. Kiai dan Perubahan Sosial, (Jakarta: P3M, 1987)

Hoogerwerf A. Ujung Kulon: the land of the last Javan Rhinos. Part V. The Javan Deer. (Leiden E. J. Brill, 1970)

Juliansyah Noor. Metodologi Penelitian Skripsi, Tesis dan Disertasi Karya Ilmiah. Cetakan Kedua. (Jakarta: Kencana Prenada Media, 2012)

Moleong, J Lexy, Metode Penelitian Kualitatif. (Bandung: PT. Remaja Rosdakaya, 2009)

Mujani, Saiful Dkk. Kuasa Rakyat. (Jakarta : Mizan Publika, 2012)

https://surabaya.tribunnews.com/2019/05/03/pemilu-adil-dan-transparan-inipesan-sejumlah-tokoh-agama-di-pasuruan-pasca-pemilu-2019__di upload pada Jumat, 3 Mei 2019 14:50

https://m.suara.com/partner/content/suarajatimpost/2019/05/20/062341/toko h-agama-kecamatan-bangil-turut-menolak-keras-people-power

https://sabdanews.com/2019/05/18/mui-kecamatan-tosari-pasuruan-serukanmasyarakat-tak-terprovokasi-people-power/ 